\title{
Effects of the intense summer desiccation and the autumn filling on the water chemistry in some Mediterranean ponds
}

\author{
Margarita Fernández-Aláez \& Camino Fernández-Aláez*
}

Department of Biodiversity and Environmental Management, Faculty of Biological and Environmental Sciences, University of León, 24071, León, Spain.

*Corresponding author: camino.alaez@unileon.es

Received: 30/2/09 Accepted: 8/7/09

\begin{abstract}
Effects of the intense summer desiccation and the autumn filling on the water chemistry in some Mediterranean ponds

The objective of this research was to compare the effects of evaporation and total desiccation, as well as the influence of the rate of refilling, on the concentrations of major ions and nutrients (nitrogen and phosphorus) in Mediterranean ponds. Water level fluctuations in these ecosystems can have a decisive role in community structuring and functioning and may affect their conservation values. The results obtained enable an assessment of the consequences of water quality changes resulting from the increased evaporation, drastic fluctuations in water levels and higher incidence of droughts in summer. Desiccation was observed to cause an increase in the bicarbonate and chloride concentrations, whilst sulphate content was frequently found to have decreased. With respect to nutrients, a drastic reduction in water volume increased orthophosphate levels, with a consequent drop in the N-nitrate: SRP ratio. Pond refilling following total desiccation resulted in higher total anion content, especially among the waters with higher mineral content, the extent of which was related to the rate of refilling. When refill followed desiccation, sulphate concentrations increased the most, whilst alkalinity decreased in most ponds. An increase in chloride concentration was only observed when refilling occurred slowly. Orthophosphate and nitrate concentrations increased at the start of the refilling period, although the most pronounced increase was in nitrate which, together with potassium, was probably washed into the ponds through soil leaching following autumn rainfall.
\end{abstract}

Key words: Ponds, ionic composition, nutrients, hydroperiod, evaporation, refilling.

\section{RESUMEN}

Efectos de la intensa desecación estival y del llenado otoñal sobre la composición química del agua de lagunas mediterráneas

El objetivo de este estudio ha sido comparar los efectos de la evaporación y la desecación completa, así como de la tasa de llenado sobre las concentraciones de los principales iones y nutrientes (nitrógeno y fósforo) en un conjunto de lagunas mediterráneas. Las fluctuaciones del nivel del agua en estos ecosistemas pueden ser determinantes de la estructura y funcionamiento de las comunidades y afectar a su conservación. Los resultados obtenidos permiten hacer una valoración de las consecuencias de los cambios en la calidad del agua derivados del aumento de la evaporación, las drásticas fluctuaciones del nivel del agua y la incidencia de las sequías estivales. En las lagunas estudiadas la desecación causó un aumento de las concentraciones de bicarbonato y cloruro, mientras que fue habitual una disminución del contenido de sulfato. Por lo que se refiere a los nutrientes, la drástica disminución del volumen de agua provocó un aumento de los niveles de ortofosfato, con la consiguiente disminución de la relación N-nitrato:P-ortofosfato. El llenado de las lagunas que siguió a la sequía total condujo a un aumento del contenido total de aniones, especialmente en las lagunas más mineralizadas, que estuvo afectado además por el ritmo de llenado. Cuando la laguna se llenó rápidamente los mayores incrementos se produjeron en la concentración de sulfato, mientras que en la mayoría de las lagunas disminuyó la alcalinidad. Cuando el llenado se produjo lentamente se observó un aumento de cloruro. Las concentraciones de ortofosfato y nitrato aumentaron al inicio del periodo de llenado, aunque el aumento más destacado se registró en el contenido de nitrato, que junto con el potasio se incorporaron probablemente a las lagunas a través del lavado del suelo, que siguió a las precipitaciones de otoño.

Palabras clave: Lagunas, composición iónica, nutrientes, hidroperiodo, evaporación, llenado. 


\section{INTRODUCTION}

In Spain, and particularly in the North Iberian Plateau, small ponds abound. Many of them are temporary ponds, and they are considered as priority habitats in the European Habitat Directive. They have variable hydroperiods depending on regional climatic conditions, making them extremely sensitive to climate as they depend mainly on rainfall. Given their dependence on rainfall and groundwater, these water bodies experience marked fluctuations in water volume, contributing to create a significant diversity of habitats, which support in turn a high biological diversity. Fernández-Aláez et al (2002) reported a high floristic richness for these ponds. In addition, these small aquatic ecosystems have a significant diversifying effect in the landscape. In the Mediterranean regions, fluctuations in the water level of shallow water bodies are frequently the result of natural processes (Fernández-Aláez et al., 2004; Álvarez-Cobelas et al., 2005; Beklioglu et al., 2007), with inter- and intra-annual variations imposed by climatic conditions and by the impact of human activity (Blindow, 1992; Gafny and Gasith, 1999). Water level fluctuations in these ecosystems can have a decisive role in community structuring and functioning and may affect their conservation values. The temporary ponds are often highly unpredictable, alternating dry and wet phases of varying length from one year to the next, according to the amount of rainfall. Thus, over a complete annual hydrologic cycle, a marked contrast can be observed between wet periods (autumn and spring) when pond refill occurs, and periods of intense evaporation (summer) which produce a negative water balance. Furthermore, the small size and shallowness of these water bodies makes them highly vulnerable to small fluctuations in the variables controlling their hydrological regime.

Hydrological variability is frequently reflected in chemical variability (Comín and Williams, 1994; Tan and Beklioglu, 2005; Williams, 2006). Vangenechten et al., (1981) studied the physicochemical properties of moor land pools in relation to changes in water availability as a consequence of climatic conditions, and Meintjes et al
(1994) analysed changes to certain physicochemical parameters in small seasonal pans in relation to flooding duration. However, in spite of these studies, information on the effects of hydrologic variations on physicochemical conditions is scarce, and even more so in relation to small water bodies in the Mediterranean region.

The fundamental objective of this study was to investigate how the chemical characteristics of water bodies are affected by two situations which are commonly experienced by all Mediterranean ponds: summer desiccation and autumn refilling. The results obtained enable an assessment to be made of the consequences of water quality changes resulting from the increase evaporation, drastic fluctuations in water levels and higher incidence of droughts in summer, all of which are predicted by models of climatic change (Coops et al., 2003; Álvarez-Cobelas et al., 2005; Nöges et al., 2007). An analysis of the effects of hydrological variations on the chemical characteristics and quality of water is an applied question of climatic change, the results of which are still uncertain.

\section{MATERIALS AND METHODS}

\section{Study area}

Research was carried out on 13 ponds located in north-western Spain, in a relatively homogeneous landscape consisting of flatlands lying between 750 and $950 \mathrm{~m}$ above sea level. Seven of the ponds studied are temporary (Table 1) and the length of their hydroperiod depends on rainfall, which usually peaks in autumn and spring. Six of the ponds are permanent, but experience a severe reduction in water volume during the summer.

The ponds are shallow (maximum depth $200 \mathrm{~cm})$ and not very big (0.6-3 ha) except for one (of $16 \mathrm{ha}$ ), and are fed by a combination of groundwater and rainfall (Fernández Aláez et al., 2006). Most of the ponds are surrounded by agricultural fields. Their main characteristics are presented in Table 1.

The area possesses a Mediterranean climate with hot dry summers and cool rainy winters (mean temperature in July is $20^{\circ} \mathrm{C}$ and mean 
Table 1. Morphometric and geographical characteristics and water permanence in the studied ponds (T: temporary, P: permanent). Características morfométricas, geográficas y de permanencia del agua en las lagunas estudiadas (T: temporales, P: permanentes).

\begin{tabular}{lcccc}
\hline Ponds & Altitude $(\mathrm{m})$ & Area $(\mathrm{Ha})$ & Maximun Depth $(\mathrm{cm})$ & Persistence \\
\hline 1-Espino & 900 & 1.7 & 100 & $\mathrm{~T}$ \\
2-Monte & 870 & 0.6 & 100 & $\mathrm{~T}$ \\
3-Valdepolo & 925 & 1.2 & 100 & $\mathrm{P}$ \\
4-Estorrubio & 900 & 0.8 & 150 & $\mathrm{~T}$ \\
5-Melgan & 789 & 2.2 & 150 & $\mathrm{P}$ \\
6-Del Redos & 900 & 1.0 & 180 & $\mathrm{P}$ \\
7-Rey & 860 & 2.5 & 200 & $\mathrm{P}$ \\
8-Sta. Cristina & 800 & 0.05 & 200 & $\mathrm{~T}$ \\
9-Balastrera & 800 & 2.7 & 150 & $\mathrm{P}$ \\
10-Grande & 830 & 16.2 & 200 & $\mathrm{~T}$ \\
11-Villamarco & 840 & 1.7 & 150 & $\mathrm{~T}$ \\
12-Mayor & 840 & 0.6 & 100 & $\mathrm{~T}$ \\
13-Seca & 810 & 3.0 & 200 & \\
\hline
\end{tabular}

annual precipitation, $533 \mathrm{~mm}$ ). The dominant lithology in the study area consists of low-thickness post-Tertiary deposits ("rañas" and alluvial terraces) which superficially cover the great Tertiary detritic deposits.

\section{Sampling and analysis}

Water samples were taken seasonally (May 1994, July 1994, November 1994, February 1995, May 1995, July 1995, November 1995 and February 1996) at a sampling station situated in the centre of each pond. At the same time, depth in the sampling station was measured in order to check water level changes. The following parameters were measured in situ: temperature, dissolved oxygen and its saturation percentage, conducti- vity and $\mathrm{pH}$, using a GRANT/YSI "Water Quality Logger 3800" measurement system. Samples were also collected at each pond for chemical analysis. In the laboratory, the following analyses were carried out on water samples: total alkalinity by titration with sulphuric acid (APHA, 1989); sulphate by turbidimetry (APHA, 1989); chloride using selective electrode; calcium, magnesium, sodium and potassium with Inductively Coupled Plasma Spectrometry (ICP); N-nitrate by reduction to nitrite on spongy cadmium and spectrophotometric measurement (Mackereth et al., 1978); $\mathrm{N}$-ammonium by indophenol blue formation and spectrophotometry (APHA, 1989); and P-orthophosphate (SRP) using molybdenum blue formation and spectrophotometric determination (Murphy and Riley, 1962).

Table 2. Depth values $(\mathrm{cm})$ in the studied ponds measured seasonally in the sampling station. Valores estacionales de profundidad $(\mathrm{cm})$ medidos en la estación de muestreo.

\begin{tabular}{lcccccrrr}
\hline Ponds & Sp94 & Su94 & Au94 & Wi95 & Sp95 & Su95 & Au95 & Wi96 \\
\hline 1-Espino & 60 & 10 & 0 & 37 & 0 & 0 & 35 & 70 \\
2-Monte & 65 & 30 & 0 & 20 & 0 & 0 & 0 & 74 \\
3-Valdepolo & 62 & 40 & 10 & 49 & 37 & 20 & 40 & 65 \\
4-Estorrubio & 60 & 10 & 0 & 29 & 0 & 0 & 38 & 70 \\
5-Melgan & 70 & 35 & 50 & 60 & 40 & 0 & 50 & 100 \\
6-Del Redos & 75 & 37 & 54 & 70 & 45 & 0 & 52 & 80 \\
7-Rey & 90 & 39 & 65 & 73 & 40 & 15 & 56 & 200 \\
8-Sta. Cristina & 70 & 45 & 65 & 70 & 42 & 0 & 0 & 80 \\
9-Balastrera & 60 & 20 & 51 & 63 & 35 & 0 & 55 & 75 \\
10-Grande & 72 & 45 & 23 & 65 & 37 & 0 & 21 & 70 \\
11-Villamarco & 54 & 0 & 26 & 64 & 28 & 0 & 50 & 60 \\
12-Mayor & 60 & 35 & 43 & 61 & 35 & 0 & 0 & 60 \\
13-Seca & 54 & 10 & 15 & 51 & 32 & 0 & 0 & 80 \\
\hline
\end{tabular}




\section{Data Analysis}

Pearson's correlations were performed to find cross-correlations among the different ions and between these and conductivity. In addition, a Principal Component Analysis (PCA) was carried out using the following water physicochemical characteristics: $\mathrm{pH}$, oxygen, conductivity, total alkalinity, sulphate, chloride, calcium, magnesium, sodium, potassium, nitrate, ammonium and orthophosphate.

For both analyses, the Kolmogorov-Smirnov test was used to check the normality of the variables and, where necessary, data were log transformed $(\log x+0.001)$.

Statistica 6.0 was used for univariate analyses and the multivariate analysis was carried out using the software CANOCO v.4.5.

\section{RESULTS}

Precipitation levels in the study area for the period January 1994-March 1996 were extremely variable, with significant seasonal and interannual differences. There was abundant rainfall in the spring of 1994, reaching a total of $100 \mathrm{~mm}$ in May, followed by a sharp decrease during the summer months, with a minimum of $3.9 \mathrm{~mm}$ in July. Nevertheless, practically all the ponds retai- ned some water throughout the summer, although with greatly reduced volume. By the end of summer, however, the majority of the ponds were dry, and some even remained dry into the autumn (Table 2). Although they later refilled with water, precipitation levels were not high, and these same ponds were the first to dry up in the following spring. Precipitation levels were extremely low in the spring of 1995 , with a minimum of $7.4 \mathrm{~mm}$ in March 1995. Low rainfall caused a considerable reduction in the water level entering the ponds, with the result that the majority of them became dry that summer (Table 2). Some ponds even became dry in the spring, and others continued to be dry well into the autumn. Although autumn rains contributed to pond refill, their water level remained low during this season. Thus, two periods of intense evaporation (summer 1994 and spring 1995), and two periods of desiccation (the end of summer 1994, and summer 1995) were recorded for the ponds. In all cases, the ponds were later refilled by autumn precipitations

Table 3 gives the mean values and variation range for conductivity and total anion content in the ponds studied. In general, total anion concentration and conductivity ranges at each pond were wide, especially in ponds with high mineral content.

In the principal component analysis carried out on all pond samples collected between spring 1994 and winter 1996, axes 1 and 2 explain $41 \%$

Table 3. Means and range of variation of conductivity and total anion content in the studied ponds. Valores medios y rangos de variación de la conductividad y del contenido total de aniones en las lagunas estudiadas.

\begin{tabular}{|c|c|c|c|c|}
\hline \multirow[t]{2}{*}{ Ponds } & \multicolumn{2}{|c|}{ Total anions $\left(\mathrm{meql}^{-1}\right)$} & \multicolumn{2}{|c|}{ Conductivity $\left(\mathrm{uScm}^{-1}\right)$} \\
\hline & $\overline{\text { Mean }}$ & Range & Mean & Range \\
\hline Espino & 3.07 & $1.27-4.63$ & 289 & $142-378$ \\
\hline Monte & 3.22 & $1.81-6.24$ & 337 & $182-650$ \\
\hline Valdepolo & 4.38 & $1.45-10.19$ & 409 & $116-894$ \\
\hline Estorrubio & 4.68 & $1.47-8.87$ & 396 & $158-598$ \\
\hline Melgán & 5.24 & $3.11-6.90$ & 460 & $280-584$ \\
\hline Del Redos & 5.88 & $2.44-9.77$ & 540 & $240-888$ \\
\hline Rey & 6.12 & $1.54-18.66$ & 459 & $164-1083$ \\
\hline Sta. Cristina & 6.15 & $2.91-17.85$ & 537 & $266-1478$ \\
\hline Balastrera & 7.67 & $5.25-14.94$ & 676 & $338-1308$ \\
\hline Grande & 11.31 & $3.51-27.96$ & 844 & $322-1614$ \\
\hline Villamarco & 11.68 & $4.40-17.98$ & 960 & $384-1508$ \\
\hline Mayor & 16.59 & $2.67-48.44$ & 1469 & $198-3860$ \\
\hline Seca & 25.47 & $2.11-85.55$ & 1847 & $188-5750$ \\
\hline
\end{tabular}


and $14.2 \%$ of the variation, and had eigenvalues of 0.41 and 0.14 respectively.

The main gradient identified with PCA was related to changes in the ionic concentration, basically associated with chloride and all the major cations except potassium. Moreover, the second axis established a tendency related to $\mathrm{pH}$ and oxygen, although sulphate, nitrate and potassium also showed a high negative correlation with this axis. The positive extreme of axis 2 was defined by alkalinity (Fig. 1).

\section{Effects of intense evaporation on the chemical characteristics of the water}

The reduction of water volume due mainly to evaporation in summer 1994 and spring 1995 caused a substantial increase in the total ion concentration in the ponds (Table 4). On average, the total anion concentration increased 1.4-fold in summer 1994 and 1.2-fold in spring 1995. In several ponds, the total concentration of anions increased about 2 -fold. The most extreme exam-

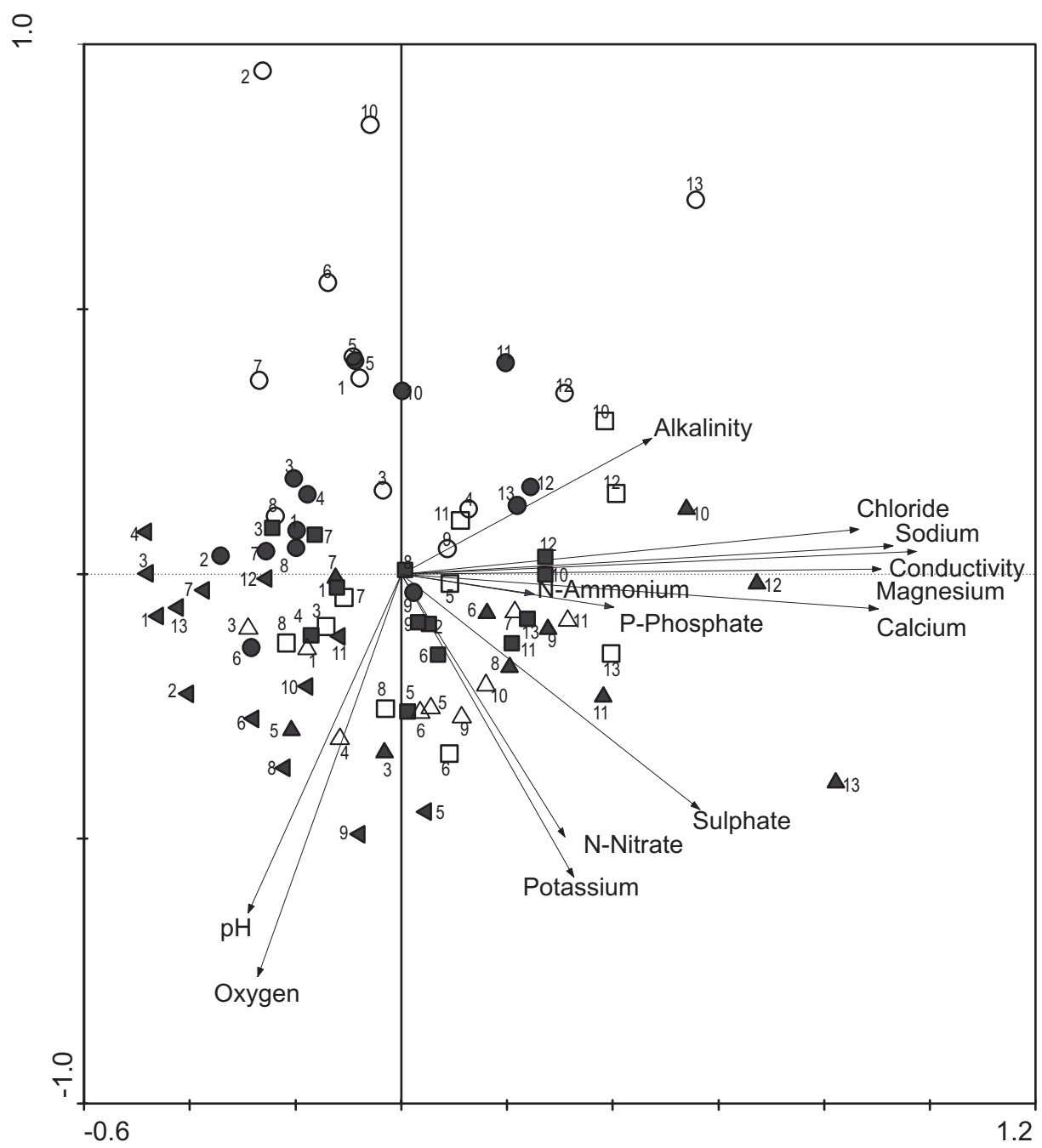

Figure 1. PCA ordination diagram of $1^{\text {st }}$ and $2^{\text {nd }}$ axes obtained from 13 water variables and 46 samples. Numbers identifying ponds are those used in table 1. O Spring 1994, $\square$ Summer 1994, $\triangle$ Autumn 1994, ○ Spring 1995, $\mathbf{0}$ Summer 1995, $\triangle$ Autumn 1995, ४Winter 1996. Diagrama de ordenación ACP (ejes 1 y 2) obtenido a partir de 13 variables físico-químicas y 46 muestras. Los números que identifican a las lagunas se recogen en la tabla 1. O Primavera 1994, $\square$ Verano 1994, $\triangle$ Otoño 1994,

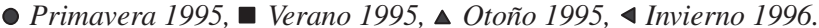


ples were recorded for those ponds still holding water although with very low levels, in summer 1995 (Rey and Valdepolo). The anion concentrations at these ponds were four times higher in the summer than in the previous winter.

In both 1994 and 1995, bicarbonate and especially chloride were involved in rising mineral concentration due to decreasing water levels (Table 4). In several ponds, chloride concentrations practically doubled, and in the most extreme example, tripled (1.2 meq $\mathrm{l}^{-1}-3.9 \mathrm{meq}^{-1}$ ) between the spring and summer of 1994. With regard to this result, the correlation between conductivity and chloride increased from 0.59 $(p=0.070)$ in winter 1995 to $0.74(p=0.014)$ in spring 1995 . The increase in bicarbonate was not so generalised. On the other hand, sulphate levels generally fell to a varying extent in all ponds, especially in summer 1994 (Table 4).

At the time of highest water level, during the spring of 1994, the predominant anions were bi- carbonate and chloride, constituting an average of $46 \%$ and $38 \%$ of total anion concentration, respectively. In winter 1995, most ponds showed similar percentages of three major anions as a result of a rise in sulphate levels the previous autumn. Throughout both annual cycles, the predominance of bicarbonate and chloride rose, and sulphate levels fell, as water level reduced. This effect was especially the case in summer 1994, when sulphate constituted less than $10 \%$ of total anion concentration in practically all the ponds, whereas during the spring values typically ranged between $20 \%$ and $30 \%$ (Fig. 2).

With respect to the cations, evaporation principally affected sodium concentrations, with 1.4fold average increase, and a general rise in magnesium levels was also noticed (Table 4). These changes were seen in ponds with both high and low mineral contents. In several ponds, magnesium concentrations doubled, whilst sodium concentrations increased 3.7 -fold (from $0.43 \mathrm{meq}^{-1}$

Table 4. Means and range of variation of ions and nutrients in spring and summer 1994 and winter and spring 1995 in the studied ponds. Valores medios y rangos de variación de iones y nutrientes en primavera y verano de 1994 y en invierno y primavera de 1995 en las lagunas estudiadas.

\begin{tabular}{|c|c|c|c|c|c|}
\hline & & $\begin{array}{c}\text { Spring } 1994 \\
n=12\end{array}$ & $\begin{array}{c}\text { Summer } 1994 \\
n=12\end{array}$ & $\begin{array}{c}\text { Winter } 1995 \\
n=10\end{array}$ & $\begin{array}{c}\text { Spring } 1995 \\
n=10\end{array}$ \\
\hline Total anions (meq $1^{-1}$ ) & $\begin{array}{l}\text { Mean } \\
\text { Range }\end{array}$ & $\begin{array}{c}4.96 \\
2.34-11.50\end{array}$ & $\begin{array}{c}7.16 \\
2.46-21.10\end{array}$ & $\begin{array}{c}7.94 \\
2.94-13.00\end{array}$ & $\begin{array}{c}9.33 \\
3.01-19.54\end{array}$ \\
\hline Alkalinity $\left(\mathrm{meq} 1^{-1}\right)$ & $\begin{array}{l}\text { Mean } \\
\text { Range }\end{array}$ & $\begin{array}{c}2.29 \\
0.33-4.17\end{array}$ & $\begin{array}{c}3.66 \\
0.79-10.45\end{array}$ & $\begin{array}{c}2.73 \\
0.70-6.47\end{array}$ & $\begin{array}{c}3.24 \\
0.56-7.00\end{array}$ \\
\hline Chloride (meq $1^{-1}$ ) & $\begin{array}{l}\text { Mean } \\
\text { Range }\end{array}$ & $\begin{array}{c}1.76 \\
0.71-4.48\end{array}$ & $\begin{array}{c}3.01 \\
0.78-8.43\end{array}$ & $\begin{array}{c}2.75 \\
1.03-4.77\end{array}$ & $\begin{array}{c}4.24 \\
0.70-11.39\end{array}$ \\
\hline Sulphate (meq $1^{-1}$ ) & $\begin{array}{l}\text { Mean } \\
\text { Range }\end{array}$ & $\begin{array}{c}0.92 \\
0.03-3.07\end{array}$ & $\begin{array}{c}0.49 \\
0.02-2.21\end{array}$ & $\begin{array}{c}2.45 \\
0.29-5.06\end{array}$ & $\begin{array}{c}1.85 \\
0.02-6.12\end{array}$ \\
\hline Calcium (meq $1^{-1}$ ) & $\begin{array}{l}\text { Mean } \\
\text { Range }\end{array}$ & $\begin{array}{c}2.32 \\
1.01-4.46\end{array}$ & $\begin{array}{c}2.79 \\
1.14-6.55\end{array}$ & $\begin{array}{c}3.55 \\
1.26-5.70\end{array}$ & $\begin{array}{c}2.91 \\
1.03-5.78\end{array}$ \\
\hline Magnesium (meq $\left.1^{-1}\right)$ & $\begin{array}{l}\text { Mean } \\
\text { Range }\end{array}$ & $\begin{array}{c}1.22 \\
0.38-2.37\end{array}$ & $\begin{array}{c}1.38 \\
0.49-3.96\end{array}$ & $\begin{array}{c}1.61 \\
0.33-3.15\end{array}$ & $\begin{array}{c}1.97 \\
0.53-4.42\end{array}$ \\
\hline Sodium (meq $\left.1^{-1}\right)$ & $\begin{array}{l}\text { Mean } \\
\text { Range }\end{array}$ & $\begin{array}{c}1.15 \\
0.43-3.46\end{array}$ & $\begin{array}{c}1.62 \\
0.42-6.36\end{array}$ & $\begin{array}{c}1.72 \\
0.61-3.99\end{array}$ & $\begin{array}{c}2.41 \\
0.41-7.42\end{array}$ \\
\hline Potassium (meq $\left.1^{-1}\right)$ & $\begin{array}{l}\text { Mean } \\
\text { Range }\end{array}$ & $\begin{array}{c}0.17 \\
0.04-0.18\end{array}$ & $\begin{array}{c}0.15 \\
0.00-0.46\end{array}$ & $\begin{array}{c}0.24 \\
0.07-6.47\end{array}$ & $\begin{array}{c}0.25 \\
0.05-0.61\end{array}$ \\
\hline P-Phosphate $\left(\mu \mathrm{g}^{-1}\right)$ & $\begin{array}{l}\text { Mean } \\
\text { Range }\end{array}$ & $\begin{array}{c}8.69 \\
0.00-53.21\end{array}$ & $\begin{array}{c}13.76 \\
2.23-68.23\end{array}$ & $\begin{array}{c}6.93 \\
0.15-15.77\end{array}$ & $\begin{array}{c}82.10 \\
6.26-531\end{array}$ \\
\hline $\mathrm{N}$-Nitrate $\left(\mathrm{mg} \mathrm{l}^{-1}\right)$ & $\begin{array}{l}\text { Mean } \\
\text { Range }\end{array}$ & $\begin{array}{c}0.69 \\
0.30-1.41\end{array}$ & $\begin{array}{c}0.77 \\
0.26-2.48\end{array}$ & $\begin{array}{c}1.17 \\
0.29-2.29\end{array}$ & $\begin{array}{c}1.25 \\
0.50-2.08\end{array}$ \\
\hline N-Ammonium $\left(\mu \mathrm{g} \mathrm{l}^{-1}\right)$ & $\begin{array}{l}\text { Mean } \\
\text { Range }\end{array}$ & $\begin{array}{c}92 \\
0.00-33\end{array}$ & $\begin{array}{c}292 \\
16.10-3100\end{array}$ & $\begin{array}{c}82 \\
8.30-201\end{array}$ & $\begin{array}{c}165 \\
37.50-404\end{array}$ \\
\hline
\end{tabular}



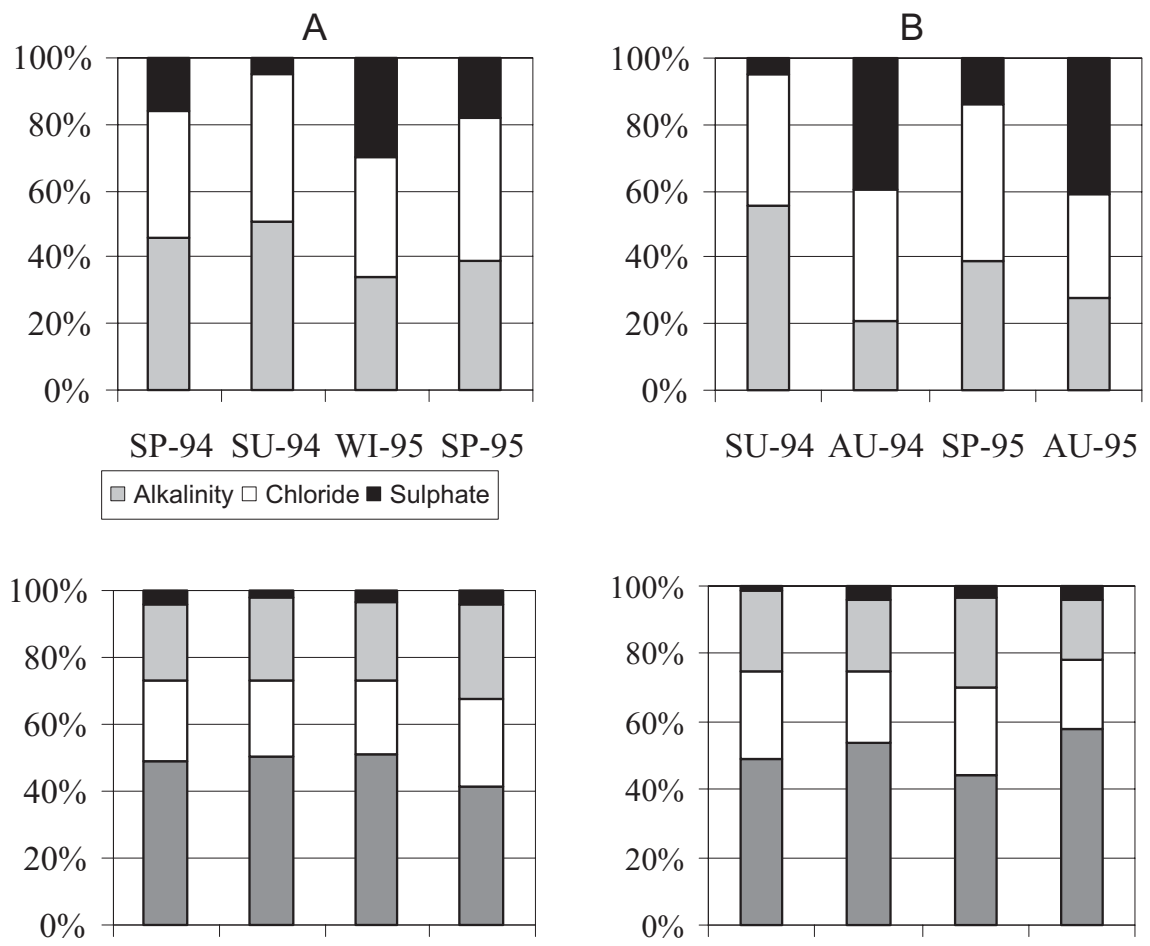

SP-94 SU-94 WI-95 SP-95

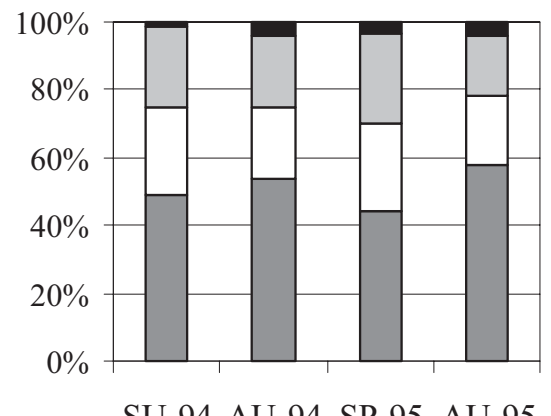

$\square$ Calcium $\square$ Magnesium $\square$ Sodium $\square$ Potassium

Figure 2. Mean percentage of anions and cations (for meq1 ${ }^{-1}$ data) in each season ordered to show: A) Effect of intense evaporation. B) Effect of drought and the subsequent refilling. Porcentaje medio de aniones y cationes (con datos en meql ${ }^{-1}$ ) en cada estación del año ordenados para mostrar: A) Efecto de la evaporación intensa. B) Efecto de la sequía y posterior llenado.

in spring to $1.6 \mathrm{meq}^{-1}$ in summer 1994). The increase in the correlation between sodium and conductivity from $0.58(p=0.08)$ in winter 1995 to $0.93(p=0.0001)$ in spring 1995 was indicative of the greater implication of chloride in the mineral concentration of the waters. Calcium and potassium levels rose in a smaller number of ponds, and in many cases they even fell (Table 4). Significant decreases of calcium concentrations were associated with $\mathrm{pH}$ increases. In spite of these changes, calcium remained the predominant cation in all ponds (Fig. 2).

With regard to nutrients, there was a marked increase in orthophosphate concentrations during the decrease of the water volume in summer (Table 4). This increase was recorded for almost all of the ponds, and was most pronounced during the 1995 period of desiccation, multiplied by a factor between 1.7 and 47 with respect to con- centrations recorded for winter. The maximum orthophosphate concentration increase was from $15.8 \mu \mathrm{g} \mathrm{l}^{-1}$ in winter to $531 \mu \mathrm{g} \mathrm{l^{-1 }}$ in spring 1995 . Unlike orthophosphate, increases in nitrate concentrations during the period of desiccation were of a lesser magnitude (Table 4). Nevertheless, in some ponds nitrate concentrations increased 2-fold, from 1.1 to $2.4 \mathrm{mg} \mathrm{l}^{-1}$ and from 0.71 to $1.44 \mathrm{mg} \mathrm{l}^{-1}$. On the other hand, ammonium concentrations rose markedly in nearly all the ponds, increasing by a factor of up to 50 . This coincided with a pronounced decrease in oxygen levels at the bottom, with values ranging between $0.9 \mathrm{mg} \mathrm{l}^{-1}$ and $2.9 \mathrm{mg} \mathrm{l}^{-1}$.

The marked increase in orthophosphate levels during the spring of 1995 brought about a more than 10 fold reduction in N-nitrate:SRP ratio (in mass) in practically all the ponds, with mean values of 890 in winter and 82 in spring. 
Pond ordination within the space defined by the first two PCA axes summarised the changes observed in ion composition and nutrient content due to desiccation. For spring 1995 samples and, above all, summer 1994 samples, displacement towards the positive extreme of axis 2 was observed compared to samples from previous periods (Fig. 1), fundamentally as a result of the reduction in sulphate and increase in bicarbonates. Likewise, some samples reflecting the effect of intense evaporation, especially those from the ponds with higher mineral contents, tended to occupy a position towards the extreme end of high ionic concentration, associated with chloride (the extreme positive end of axis 1) (Fig. 1). This position also reflected a positive relation with phosphate and ammonium, and a negative relation with oxygen concentration.

\section{Effects of drought and the subsequent refilling of the ponds on the chemical characteristics of water}

In most ponds that dried out completely during the summer time, refilling in the autumn of 1994 resulted in increased ion concentrations (Table 5), with greatest changes being observed in the ponds with higher mineral content, where total anion concentrations multiplied by a factor between 1.2 and 5. In ponds with a lower mineral content this tendency was not so marked, and in some cases a slight reduction in ion concentrations was registered. On average, total anion concentration increased 3-fold, and in the most extreme case increased 5-fold, from $3.5 \mathrm{meq}^{-1}$ to $17.8 \mathrm{meq}^{-1}$. As it would be expected from these results, conductivity increased on average by 2.4 ,

Table 5. Means and range of variation of ions and nutrients in summer and autumn 1994 and spring and autumn 1995 in the studied ponds. Valores medios y rangos de variación de iones y nutrientes en verano y otoño de 1994 y primavera y otoño de 1995 en las lagunas estudiadas.

\begin{tabular}{|c|c|c|c|c|c|}
\hline & & $\begin{array}{c}\text { Summer } 1994 \\
n=9\end{array}$ & $\begin{array}{c}\text { Autumn } 1994 \\
n=9\end{array}$ & $\begin{array}{c}\text { Spring } 1995 \\
\quad n=7\end{array}$ & $\begin{array}{c}\text { Autumn } 1995 \\
n=7\end{array}$ \\
\hline \multirow[t]{2}{*}{ Total anions (meq $1^{-1}$ ) } & Mean & 7.78 & 23.75 & 8.10 & 8.95 \\
\hline & Range & $2.89-21.10$ & $3.11-85.55$ & $3.82-16.90$ & $2.73-18.66$ \\
\hline \multirow[t]{2}{*}{ Alkalinity (meq $1^{-1}$ ) } & Mean & 4.13 & 3.11 & 3.27 & 2.25 \\
\hline & Range & $1.09-10.45$ & $0.29-13.89$ & $0.56-7.00$ & $0.09-5.94$ \\
\hline \multirow[t]{2}{*}{ Chloride (meq $\mathrm{l}^{-1}$ ) } & Mean & 3.11 & 9.11 & 3.81 & 2.84 \\
\hline & Range & $0.78-8.43$ & $0.81-35.25$ & $1.52-8.60$ & $0.78-4.50$ \\
\hline \multirow[t]{2}{*}{ Sulphate (meq $1^{-1}$ ) } & Mean & 0.55 & 11.53 & 1.01 & 3.86 \\
\hline & Range & $0.02-2.21$ & $0.34-48.05$ & $0.02-2.15$ & $1.46-11.53$ \\
\hline \multirow[t]{2}{*}{ Calcium (meq $1^{-1}$ ) } & Mean & 2.98 & 10.30 & 2.69 & 4.58 \\
\hline & Range & $1.33-6.59$ & $1.14-6.55$ & $1.45-5.15$ & $1.58-8.12$ \\
\hline \multirow[t]{2}{*}{ Magnesium (meq $\mathrm{l}^{-1}$ ) } & Mean & 1.66 & 4.49 & 1.76 & 1.62 \\
\hline & Range & $0.49-3.96$ & $0.64-16.41$ & $0.54-4.43$ & $0.39-2.63$ \\
\hline \multirow[t]{2}{*}{ Sodium (meq 1 $\mathrm{l}^{-1}$ ) } & Mean & 1.81 & 4.55 & 1.67 & 1.35 \\
\hline & Range & $0.42-6.36$ & $0.46-18.01$ & $0.82-3.90$ & $0.64-2.71$ \\
\hline \multirow[t]{2}{*}{ Potassium (meq $1^{-1}$ ) } & Mean & 0.11 & 0.58 & 0.22 & 0.37 \\
\hline & Range & $0.00-0.46$ & $0.14-1.81$ & $0.05-0.61$ & $0.10-1.28$ \\
\hline \multirow[t]{2}{*}{ P-Phosphate $\left(\mu \mathrm{g} \mathrm{1^{-1 }}\right)$} & Mean & 16.27 & 36.74 & 32.86 & 61.47 \\
\hline & Range & $2.23-68.23$ & $5.70-258$ & $6.26-146$ & $0-334$ \\
\hline \multirow[t]{2}{*}{ N-Nitrate $\left(\mathrm{mg} \mathrm{l}^{-1}\right)$} & Mean & 0.87 & 2.28 & 1.15 & 9.03 \\
\hline & Range & $0.44-2.40$ & $0.39-9.51$ & $0.50-1.44$ & $0.29-24.70$ \\
\hline \multirow[t]{2}{*}{ N-Ammonium $\left(\mu \mathrm{g}^{-1}\right)$} & Mean & 37.60 & 407 & 156 & 561 \\
\hline & Range & $16.10-78.40$ & $15.40-2260$ & $37.50-404$ & $9.30-3470$ \\
\hline
\end{tabular}


with a maximum value of $5750 \mu \mathrm{S} \mathrm{cm}^{-1}$, whereas previous to desiccation, highest pond conductivity was $1930 \mu \mathrm{Scm}^{-1}$. These results can be seen in the pond ordination diagram, where autumn 1994 samples, especially those from waters with high mineral content, tend to occupy positions on the positive end of axis 1 (Fig. 1).

During the second annual cycle, desiccation and the subsequent refilling of the ponds did not result in a general rise in total anion concentration, and mean overall values for the ponds in spring and autumn 1995 were 8.10 and $8.95 \mathrm{meq}^{-1}$ respectively (Table 5). Neither was there a general increase in conductivity, with mean values for before and after desiccation being 679 and $615 \mu \mathrm{S} \mathrm{cm}^{-1}$ respectively.

Sulphate concentration was especially affected by refilling following desiccation, showing an increase across all the ponds both in autumn 1995 and autumn 1994. This increase was especially pronounced in autumn 1994, with concentrations registered in the summer increasing by a factor of between 2 and 600. Moreover, during refill the correlations between sulphate and all cations increased with respect to values recorded before drought (Table 6). Chloride levels, however, were only affected by autumn 1994 water refill, when concentrations rose by a factor of between 1.2 and 5. For both annual cycles, a marked reduction in alkalinity was observed at the start of the refilling period, in autumn, as compared to values recorded before desiccation (Table 5) and the correlations between alkalinity and all cations decreased (Table 6). Moreover, the desiccation and the subsequent refilling of the ponds in- duced changes in the percentages of anions. Prior to desiccation, bicarbonate and chloride constituted the predominant ions in most ponds. However, at the start of the refilling sulphate and in some cases, chloride became the predominant anions in many of the ponds, with bicarbonate providing the smallest contribution to total ionic concentration (Fig. 2).

The effect of refilling on cation concentrations was different for each of the annual cycles. In autumn 1994, cation concentrations increased in practically all of the ponds (Table 5). In general, the most significant change was recorded for potassium, with pre-desiccation values multiplying by a factor of between 1.5 and 30 at the start of the refilling. Calcium continued to be the dominant cation in the ponds, whilst potassium represented the lowest percentage, with values of between $2 \%$ and $19 \%$ (Fig. 2). In autumn 1995, increases were mainly recorded for calcium and potassium, whilst changes to sodium and magnesium levels were variable (Table 5). Calcium continued to be the dominant cation in the ponds, whilst the proportion of magnesium and sodium decreased. The cation contributing least to total mineral concentration continued to be potassium (Fig. 2).

As for nutrients, orthophosphate concentrations increased during autumn refilling (Table 5). The extent of the increase varied among the ponds; in the most extreme case, the orthophosphate concentration multiplied by a factor of 226 , reaching a level of $259 \mu \mathrm{g} \mathrm{l^{-1 }}$. Likewise, nitrate concentrations rose considerably, but unlike orthophosphate, this increase affected practically all the ponds during both refilling periods, with increases by a factor of between 1.5 and 20 .

Table 6. Cations-sulphate and cations-alkalinity correlations before and after pond drought (S: Summer, A: Autumn, Sp: Spring) (* $p<0.05$, ** $p<0.01$, *** $p<0.001)$. Valores de correlación entre cationes y sulfato y entre cationes y alcalinidad antes y después del periodo seco (S: verano, A: otoño, Sp: primavera) $(* \mathrm{p}<0.05, * * \mathrm{p}<0.01$, *** $\mathrm{p}<0.001)$.

\begin{tabular}{|c|c|c|c|c|c|c|c|c|}
\hline & $\begin{array}{c}\text { S-94 } \\
n=9\end{array}$ & $\begin{array}{l}\text { A-94 } \\
n=9\end{array}$ & $\begin{array}{l}\text { Sp-95 } \\
n=7\end{array}$ & $\begin{array}{l}\text { A-95 } \\
n=7\end{array}$ & $\begin{array}{c}\text { S-94 } \\
n=9\end{array}$ & $\begin{array}{l}\text { A-94 } \\
n=9\end{array}$ & $\begin{array}{l}\text { Sp-95 } \\
n=7\end{array}$ & $\begin{array}{l}\text { A-95 } \\
n=7\end{array}$ \\
\hline & \multicolumn{4}{|c|}{ Alkalinity (meq $1^{-1}$ ) } & \multicolumn{4}{|c|}{ Sulphate (meq $1^{-1}$ ) } \\
\hline Calcium (meq $1^{-1}$ ) & $0.96^{* * *}$ & -0.07 & 0.64 & 0.30 & $0.90 * * *$ & $0.99 * * *$ & -0.14 & $0.80 *$ \\
\hline Magnesium (meq $1^{-1}$ ) & $0.89 * *$ & 0.21 & $0.80 * *$ & 0.40 & $0.76^{*}$ & $0.92^{* * *}$ & 0.73 & 0.70 \\
\hline Sodium $\left(\right.$ meq $1^{-1}$ ) & $0.91 * * *$ & 0.11 & 0.44 & 0.14 & $0.96 * * *$ & $0.91 * * *$ & 0.56 & $0.93 * *$ \\
\hline Potassium (meq $\mathrm{l}^{-1}$ ) & $0.78 *$ & $0.77 *$ & 0.41 & -0.41 & 0.62 & 0.43 & 0.59 & $0.90^{* *}$ \\
\hline
\end{tabular}


The increase in nitrogen concentrations was more pronounced in autumn 1995 (Table 5), reaching maximum concentrations of $24.7 \mathrm{mg} \mathrm{l}^{-1}$, compared with maximum concentrations recorded in the summer of $1.97 \mathrm{mg} \mathrm{l}^{-1}$.

In general, the N-nitrate:SRP ratio increased at the beginning of the flood periods. However, this increase was notably more pronounced in autumn 1995, with the N-nitrate:SRP ratio multiplying by a factor of up to 83 , and affecting a greater number of ponds.

In PCA ordination of the ponds, the increase in sulphate, potassium and nitrate during flood periods was a determining factor behind the displacement of the majority of autumn samples towards the lower right quadrant of the PCA plot (Fig. 1).

\section{DISCUSSION}

Hydrological variations determined changes in the ionic concentrations and composition in the north-western Spanish ponds studied. Pond salinity and major ion levels proved to be very vulnerable to evaporation and flooding following desiccation. Williams (2006) has indicated that these processes are responsible for changes in the concentration and relative abundance of dissolved substances in temporary water systems.

Various authors (Malmer, 1962; Cole, 1968; Vangenechten et al., 1981; White et al., 2008) have reported ion concentration changes during fluctuations in aquatic system water levels, and significant increases in mineral content measured via conductivity when the water level undergoes a drastic reduction due to evaporation (Cole, 1968; Rodrigo et al., 2002; Camacho et al., 2003; García-Ferrer et al., 2003). For example, Tan (2002) reports that in two shallow lakes in an arid region of Turkey, salinity levels rose drastically in response to drier hydrological conditions.

The low precipitation and intense evaporation which the majority of ponds in north-western Spain underwent in the summer of 1994 and spring of 1995 produced significant increases in ion concentration and conductivity. In contrast to the results reported by Vangenechten et al (1981) on acidic moorland ponds in Belgium, this dras- tic reduction in water volume did not, however, have the same effect on anions. As chloride is the last ion species to precipitate in conditions of evaporation, this anion and sodium constituted the two ions most closely involved in an increase in mineral content in the Spanish ponds studied. This is demonstrated by the fact that as evaporation caused the concentration of dissolved ions, the correlation with conductivity for both ions also increased. In contrast, other, less soluble salts such as calcium sulphate were more inclined to precipitate, with the consequent loss of both ion species during evaporation. Cole (1968) has indicated that this process of precipitation is a typical change in water chemistry when concentration occurs due to evaporation. The loss of calcium was compensated for by a relative increase in magnesium and sodium (Cole, 1968).

In addition, as reported by Patrick and Wyatt (1964), changes to pond hydrology affected nutrient cycles in the ponds studied. Although nitrate concentrations rose in some ponds, an increase in ammonium was both more frequent, this latter being favoured by the predominant reduction conditions present at the pond bottom. Likewise, desiccation produced a noticeable increase in orthophosphate, leading to situations of marked eutrophy. Various processes may have been involved in the chemistry of this nutrient. Firstly, calcium does not appear to have been decisive in controlling concentrations of bio-available phosphorus in this study, a question which has been discussed by several authors (Sondergaard et al., 1996; Hupfer et al., 2000). It would be reasonable to expect that in hard waters, phosphorus levels would be reduced through incorporation into precipitated calcium carbonate. However, in some of the ponds, included in this study, with high photosynthetic activity, although $\mathrm{pH}$ rose to over 9 with the consequent decrease in calcium, this did not result in a loss of orthophosphate. In the present case, a more reliable explanation would be that low water level provided longer contact with sediment, contributing to internal release of phosphorus (Karapinar, 2005; Romo et al., 2005). In addition, the predominant reduction conditions present in the pond sediment would have favoured the liberation of 
orthophosphate and, consequently, a pronounced increase in orthophosphate concentrations in the water column. Those ponds showing the most pronounced increase in this nutrient were characterised by having pond floor oxygen concentrations of less than $1 \mathrm{mg} / \mathrm{l}(<10 \%$ saturation).

The changes to nutrient concentrations produced during periods of desiccation also affected $\mathrm{N}$-nitrate:SRP ratio values, with a decrease which was especially pronounced in spring 1995 . These variations have important biological implications, especially for the phytoplanktonic communities, as the $\mathrm{N}: \mathrm{P}$ ratio is considered a fundamental factor in the predominance of cyanobacteria in warm lakes (Smith, 1983; Shapiro, 1990). For example, in a mesocosm experiment carried out at a small shallow Mediterranean lake in northwestern Spain (Fernández-Aláez et al., 2004), the predominance of a cyanobacterial Mycrocystis bloom was correlated with a low DIN:SRP ratio.

In Mediterranean regions, many shallow water bodies become completely or partially dry during the summer and even towards the end of spring. It is to be expected that this desiccation and posterior filling would have a significant effect on water chemistry (Jeffries et al., 2002; Tipping et al., 2003; Williams, 2006). As temporary water systems desiccate, organic matter located in the top sediment layer is oxidised, and evaporation at the sediment-water interface causes an upward flow of water containing the dissolved compounds (De Groot and Golterman, 1994). Thus, it is reasonable to expect changes to the chemical composition of water after flooding.

In the ponds studied in the northwest of Spain, summer droughts produced changes in the ionic concentrations and composition at the beginning of the flood periods although the results obtained appear to indicate that the rate of refill is decisive. When the ponds refilled slowly, such as in autumn 1994, a sharp increase in ion concentrations and conductivity was recorded, which was more pronounced in the waters with high mineral content waters. However, when refill occurred rapidly, as was the case following heavy rainfall in autumn 1995 , ion concentrations in the majority of the ponds did not increase, and in some cases even diminished as a result of salt dilution processes.
After flooding, large concentrations of sulphate were measured in the water. This finding has also been recorded by other authors (Vangenechten et al. 1981; Eimers and Dillon, 2002; Eimers et al., 2007), and is basically understood to be the result of oxidation of reduced $\mathrm{S}$ compounds, caused by the exposure of anoxic sediment to the air during drought (Malmer, 1960, 1962; Eimers et al., 2007). Therefore, the level of sulphate concentrations in these water systems is influenced by summer drought (Eimers \& Dillon, 2002; Eimers et al., 2004), and highest concentrations will be recorded during years of prolonged summer drought. The increase in correlations between sulphate and all cations during flooding leads to the conclusion that the excess of this anion in the water at the start of the refilling period was counteracted by all cations. In contrast, bicarbonate implication in cation chemistry diminished, especially with regard to calcium and magnesium chemistry, and a reduction, or even absence, of significant correlations was observed.

The influence of drought on chloride levels was not as evident as for sulphate levels, reflecting the findings of Wangenechten et al (1981) in their study of pools in Belgium, where chloride was not found to increase with low water levels during flooding. In the present study, it was only when refilling occurred slowly (as in autumn 1994) and pond water levels were low that an increase in chloride concentration was observed. This was probably related to sediment mobilisation processes given that chloride and sodium are the first ions to be dissolved after rainfall (Espinar and Serrano, 2009).

Slower pond refilling following desiccation favoured a general increase in all cations. However, when this process occurred more quickly, only calcium and potassium were responsive to hydrologic variations. The increase in potassium was especially pronounced, regardless of the pond refill rate, and was probably linked to soil runoff following autumn rainfall. This input of allochthonous potassium is favoured by the fact that all the ponds are located in a predominantly agricultural landscape where the potassium addition to soil is common practice. In spite of these changes, the cation order of dominance did not 
vary, and calcium remained the predominant cation in all the ponds.

High concentrations of nitrogen and phosphorus were recorded in the ponds during autumn refilling in 1994 and 1995, showing a considerable increase on levels recorded prior to desiccation. Rodrigo et al (2002) obtained similar results for shallow ponds in eastern Spain; in addition, there is evidence related to ricefields, ecosystems subject to alternative processes of desiccation and flooding, indicating that flooding releases significant quantities of nutrients, such as nitrogen in the forms of nitrate and ammonium (Forés and Comín, 1987; Forés and Sabater, 1987; Comín and Forés, 1990). In the case of phosphorus, various studies have found that high concentrations coincide with flooding after desiccation (Baldwin and Mitchell, 2000; Newman and Pietro, 2001; Young and Ross, 2001). The results of our study can be explained by the fact that pond desiccation would have accelerated the rate of organic nitrogen and phosphorus mineralisation (Gerritsen and Greening, 1989; Song et al., 2007), and these nutrients would then have been released from the sediment into the water during flooding. In addition, in the case of phosphorus, some authors have reported a desorption process of phosphate previously adsorbed in crystalline minerals, releasing it into the water during refilling (Song et al., 2007). As for nitrate, the heavier rainfall of autumn 1995, with the subsequent soil leaching, was probably a determining factor in nitrogen enrichment of the ponds during refilling.

Sample ordination in relation to the first two PCA axes produced a variation pattern for substances dissolved in the ponds studied in northwestern Spain as a result of intense evaporation, as well as indicating changes produced by desiccation followed by pond refilling.

In conclusion, this study has demonstrated that salinity and concentrations of the major ions and nutrients in ponds in the northwest of Spain are highly vulnerable to evaporation and total drought. Both processes resulted in a high concentration of most of the ions, although in the case of drought this was most pronounced when the ponds started to fill slowly. However, evapo- ration and drought had different effects on ion composition. An extreme reduction in water volume resulted above all in an excess of chloride and sodium, and a reduction in sulphate, whilst drought of the ponds favoured oxidation of reduced sulphur compounds, with the consequent increase in sulphate during refill. Likewise, soil runoff from agricultural land as a result of autumn rainfall was a determining factor in the rise in pond water potassium levels. Hydrological regimes changes resulted in substantial modifications to nutrient dynamics, probably involving various mechanisms, such as the release of phosphorus from the sediment, and the formation of ammonium, both processes which would be facilitated by a reduction in oxygen concentrations; the mineralisation of organic nitrogen and phosphorus associated with pond desiccation; and the input of nitrate from the surrounding land as a result of soil runoff caused by autumn rainfall.

In view of these results, it can be concluded that hydrological variations caused by reduced rainfall could result in environmental problems in terms of water body conservation. In particular, the increase in dissolved salts could transform some fresh water lakes into more or less salt water systems. Likewise, nutrient enrichment could accelerate the process of eutrophication in these water bodies. It should be borne in mind that these kinds of hydrological modifications will occur more frequently in the future, both as the result of increases in various anthropogenic activities, particularly over-exploitation of aquifers and the development of new irrigation networks, and the result of possible climatic changes, with severe droughts, which could give rise to frequent cycles of drought and rewetting in Mediterranean water bodies.

\section{ACKNOWLEDGEMENTS}

We would like to thank the members of the limnology group (University of León) for their assistance in laboratory and field work. This research was supported by the Junta de Castilla y León (LE27/98) and CICYT (Amb94-0292). 


\section{REFERENCES}

ÁLVAREZ-COBELAS M., J. CATALÁN \& D. GARCÍA DE JALÓN. 2005. Impactos sobre los ecosistemas acuáticos continentales. In: Evaluación preliminar de los impactos en España por efecto del cambio climático. J.M. Moreno (ed.): 113-146. Ministerio de Medio Ambiente. Madrid.

APHA. 1989. Standard Methods for the Examination of Water and Waste Water. $18^{\text {th }}$ edition. American Public Health Association. Washington, D.C. $874 \mathrm{pp}$.

BALDWIN, D. S. \& A. M. MITCHELL. 2000. The effects of drying and rewetting on the sediment and soil nutrient dynamics of lowland river floodplain systems: a synthesis. Regulated Rivers Research and Management, 16: 457-467.

BEKLIOGLU, M., S. ROMO, I. KAGALOU, X. QUINTANA \& E. BÉCARES. 2007. State of the art in the functioning of shallow Mediterranean lakes: workshop conclusions. Hydrobiologia, 584(1): 317-326.

BLINDOW, I. 1992. Long and short-term dynamics of submerged macrophytes in two shallow eutrophic lakes. Freshwat. Biol., 28: 15-27.

CAMACHO, A., M. R. MIRACLE \& E. VICENTE. 2003. Which factors determine the abundance and distribution of picocyanobacteria in inland waters? A comparison among different types of lakes and ponds. Archiv für Hydrobiologie, 157: 321-338.

COLE, G. A. 1968. Desert limnology. In: Desert Biology. G. W. Brown (ed.): 423-485. Academic Press, New York. U.S.A.

COMÍN, F. A. \& E. FORÉS. 1990. Comprobación experimental de la importancia relativa de las vías superficial y subterránea de la inundación en la liberación de sales de sedimentos desecados. Scientia gerundensis, 16:69-77.

COMÍN, F. A. \& W. D. WILLIAMS. 1994. Parched continents: our common future? In: Limnology Now: A Paradigm of Planetary Problems. R. Margalef (ed.): 473-527. Elsevier, Amsterdam.

COOPS, H., M. BEKLIOGLU \& T. L. CRISMAN. 2003. The role of water-level fluctuations in shallow lake ecosystems-workshop conclusions. $\mathrm{Hy}$ drobiologia, 506-509: 23-27.

DE GROOT, C. J. \& H. L. GOLTERMAN. 1994. Nutrient process in Mediterranean wetland systems. Part 2. The influence of desiccation. Verh. Internat. Verein. Limnol., 25: 1328.
EIMERS, M. C. \& P. I. DILLON. 2002. Climate effects on sulphate flux from forested catchment in south-central Ontario. Biogeochemistry, 61: 337355.

EIMERS, M. C., P. I. DILLON \& S. A. VATMOUGH. 2004. Long-term (18-year) changes in sulphate concentrations in two headwater lakes and their inflows in response to decreasing deposition and climate variation. Hydrological Processes, 18: 2617-2630.

EIMERS, M. C., S. A. WATMOUGH, J. M. BUTTLE \& P. J. DILLON. 2007. Drought-induced sulphate relese from a wetland in south-central Ontario. Environmental Monitoring Assessment, 127: 399-407.

ESPINAR, J. L. \& L. SERRANO. 2009. A quantitative hydrogeomorphic approach to the classification of temporary wetlands in the Doñana National Park (SW Spain) Aquatic Ecology, 43(2): 323-334.

FERNÁNDEZ-ALÁEZ, C., M. FERNÁNDEZ-ALÁEZ, C. TRIGAL \& E. LUIS. 2006. Hydrochemistry of northwest Spain ponds and its relationships to groundwaters. Limnetica, 25(1-2): 433-452.

FERNÁNDEZ-ALÁEZ, M., C. FERNÁNDEZ ALÁEZ, S. RODRÍGUEZ \& E. BÉCARES. 2002. Evaluation of the state of conservation of shallow lakes in the province of León (Northwest Spain) using botanical criteria. Limnetica, 17: 107-117.

FERNÁNDEZ-ALÁEZ, M., . FERNÁNDEZ-ALÁEZ, E. BÉCARES, M. VALENTÍN, J. GOMA \& P. CASTRILLO. 2004. A 2-year experimental study of nutrient and predator influences on food web constituents in a shallow lake of north-west Spain. Freshwat. Biol., 49: 1574-1592.

FERNÁNDEZ-ALÁEZ, M., C. FERNÁNDEZ-ALÁEZ, F. GARCÍA-CRIADO \& C. TRIGAL. 2004. La influencia del régimen hídrico sobre las comunidades de macrófitos de lagunas someras de la Depresión del Duero. Ecosistemas, 2004/2 (URL: http// www.aeet.org/ecosistemas//042/investigacion6.htm).

FORÉS, E. \& F. A. COMÍN. 1987. Chemical characteristics of the water in the ricefields of the Ebro Delta. Archiv für Hydrobiologie, 111: 15-24.

FORÉS, E. \& F. SABATER. 1987. Movilización del nitrógeno en los arrozales: interacción sedimentoagua durante la inundación. Proceedings IV Spanish Congress of Lymnology. May, 1987. Sevilla, Spain: 127-134.

GAFNY, S. \& A. GASITH. 1999. Spatially and temporally sporadic appearance of macrophytes in the 
littoral zone of Lake Kinneret, Israel: taking advantage of a window of opportunity. Aquatic Botany, 62: 249-267.

GARCÍA-FERRER, I., A. CAMACHO, X. ARMENGOL, M. R. MIRACLE \& E. VICENTE. 2003. Seasonal and spatial heterogeneity in the water chemistry of two sewage-affected saline shallow lakes from central Spain. Hydrobiologia, 506509: 101-110.

GERRITSEN, J. \& H. S. GREENING. 1989. Marsh seed bands of Okefenokee swamp: effects of hydrologic regime and nutrients. Ecology, 70(3): 750-763.

HUPFER, M., R. POETHIG, R. BRUEGGEMANN \& W. GELLER. 2000. Mechanical resuspension of autochthonous calcite (Seek reide) failed to control internal phosphorus cycle in a eutrophic lake. $W a$ ter Research, 34: 859-867.

JEFFRIES, D. S., R. G. SEMKIN, F. D. BEALL \& J. FRANKLYN. 2002. Temporal trends in water chemistry in the Turkey Lakes Watershed, Ontario, Canada, 1982-1999. Water Air and Soil Pollution. Focus, 2: 5-22.

KARAPINAR, B. 2005. Role of hydrology, sewage effluent diversion and fish on mass balance of $n u$ trients in a system of shallow Lakes Eymir and Mogan. Msc. Thesis, Middle East Technical University, Ankara, 78 pp.

MACKERETH, F. J. H., J. HERON \& J. F. TALLING. 1978. Water analysis: Some revised methods for limnologists. Scientific publication of the Freshwater Biological Association, 36. 120 pp.

MALMER, N. 1960. Some ecologic studies on lakes and brooks in the South Swedish uplands. Botaniska Notiser, 113: 87-116.

MALMER, N. 1962. Studies on mire vegetation in the Archaean area of Southwestern Götaland (South Sweden). II. Distribution and seasonal variation. Opera Botanica, 7: 1-67.

MEINTJES, S., M. T. SEAMAN \& D. J. KOK. 1994. Duration of inundation and change in physical and chemical characteristics of small temporary pans in South Africa. Hydrobiologia, 281: 79-90.

MURPHY, J. \& J. P. RILEY. 1962. A modified single solution method for the determination of phosphate in natural waters. Analytica Chimica Acta, 27: 31-36.

NEWMAN, S. \& K. PIETRO. 2001. Phosphorus storage and release in response to flooding: implications for everglades stormwater treatment areas. Ecological Engineering, 18: 23-28.
NÖGES, P., W. VAN DE BUND, A. C. CARDOSO \& A. S. HEISKANEN. 2007. Impact of climatic variability on parameters used in typology and ecological quality assessment of surface watersimplications on the Water Framework Directive. Hydrobiologia, 584: 373-379.

PATRICK, W. H. \& R. WYATT. 1964. Soil nitrogen loss as a result of alternate submergence and drying. Soil Science Society of America Proceedings, 28: 647-653.

QUINTANA, X. D., R. MORENO-AMICH \& F. A. COMÍN. 1998. Nutrient and plankton dynamics in a Mediterranean salt marsh dominated by incidents of flooding. Part 1: differential confinement of nutrients. Journal of Plankton Research, 20(11): 2089-2107.

RODRIGO, M. A., X. ARMENGOL, R. OLTRA \& W. COLOM. 2002. Physical and chemical characterization of a protected wetland area in El Fondo d'Elx (Alicante, Spain). Limnetica, 21(1-2): 37-46.

ROMO, S., M. J. VILLENA, M. SAHUQUILLO, J. M. SORIA, M. JIMÉNEZ, T. ALFONSO, E. VICENTE AND M. R. MIRACLE. 2005. Response of a shallow Mediterranean lake to nutrient diversion: does it follow similar patterns as in northern shallow lakes? Freshwat. Biol., 50: 1706-1717.

SHAPIRO, J. 1990. Current beliefs regarding dominance by blue-greens: the case for the importance of $\mathrm{CO}_{2}$ and $\mathrm{pH}$. Verh. Internat. Verein. Limnol., 24: $38-54$

SMITH, V. H. 1983. Low nitrogen to phosphorus ratios favor dominance by blue-green algae in lake phytoplankton. Science, 221: 669-671.

SONDERGAARD, M., J. WINDOLF \& E. JEPPESEN. 1996. Phosphorus fractions and profiles in the sediment of shallow Danish lakes as related to phosphorus load sediment composition and lake chemistry. Water Research, 30: 992-1002.

SONG, K. Y., K. D. ZOH \& H. KANG. 2007. Release of phosphate in a wetland by changes in hydrological regime. Science of Total Environment, 380: 13-18.

TAN, C. O. \& M. BEKLIOGLU. 2005. Catastrophiclike shifts in two Turkish lakes: a modelling approach. Ecological Modelling, 183: 425-434.

TAN, C. O. 2002. The roles of hydrology and nutrients in alternative equilibrium of two shallow lakes of Anatolia. Lake Eymir and Lake Mogan: using monitoring and modelling approaches. MSc Thesis. Middle East Technical University. Ankara, Turkey. 144 pp. 
TIPPING, E., E. J. SMITH, A. J. LAWLOR, S. HUGHES \& P. A. STEVENS. 2003. Predicting the release of metals from ombrotrophic peat due to drought-induced acidification. Environmental Pollution, 123: 239-253.

VANGENECHTEN, J. H. D., F. BOSMANS \& H. DECKERS. 1981. Effects of short-term changes in rain water supply on the ionic composition of acid moorland pools in the campine of Antwerp (Belgium). Hydrobiologia, 76: 149-159.

WHITE, M. S., M. A. XENOPOULOS, K. HOGS-
DEN, R. A. METCALFE \& P. J. DILLON. 2008. Natural lake level fluctuation and associated concordance with water quality and aquatic communities within small lakes of the Laurentian Great Lakes region. Hydrobiologia, 613: 21-31.

WILLIAMS, D. D. 2006. The biology of temporary waters. Oxford University Press. New York. 337 pp.

YOUNG, E. O. \& D. S. ROSS. 2001. Phosphate release from seasonally flooded soils: a laboratory microcosm study. Journal of Environmental Quality, 30: 91-101. 